\title{
ANALISIS TREND PENGGUNAAN TEMPAT TIDUR DI RS PANTI WILASA CITARUM SEMARANG TAHUN 2015 - 2019
}

\section{Analysis Of The Use Of Bed Trends In RS Panti Wilasa Citarum Semarang $2015-2019$}

\author{
Maria Argina ${ }^{1}$, Asih Prasetyowati ${ }^{2}$, Reni Murnita $^{3}$, Andri Asmorowati $^{4}$ \\ ${ }^{1,2,3,4}$ Prodi Rekam Medis dan Informasi kesehatan STIKES HAKLI Semarang \\ 22dhicalove@gmail.com
}

\begin{abstract}
ABSTRAK
Latar Belakang: Analisis trend digunakan sebagai bahan perencanaan dan evaluasi untuk mencapai pelayanan rawat inap yang lebih baik. Angka penggunaan tempat tidur ditunjukkan dengan BOR, LOS, TOI, dan BTO. Angka BOR di RS Panti Wilasa Citarum pada Tahun 2015 - 2019 belum memenuhi standar efisiensi yaitu sekitar $62 \%$.

Tujuan : Penelitian ini bertujuan untuk menganalisis trend BOR, LOS, TOI, BTO dan Grfaik Barber Johnson di RS Panti Wilasa Citarum Semarang tahun 2015 2019.

Metode penelitian : Penelitian ini merupakan penelitian deskriptif dengan rancangan penelitian retrospective study. Sumber data diperoleh melalui observasi dan wawancara dengan petugas analising/reporting sedangkan data sekunder diperoleh dari RL 3. Analisa data dilakukan dengan cara menganalisa trend dan Grafik Barber Johnson.

Hasil penelitian : Trend BOR mengalami penurunan setiap tahunnya dari yang tertinggi $64,03 \%$ dan terendah $61,50 \%$. Trend LOS dan TOI mengalami penurunan setiap tahunnya sedangkan Trend BTO mengalami peningkatan setiap tahunnya. Penggunaan tempat tidur dengan Grafik Barber Johnson berada diluar efisiensi dengan trendnya menjauhi daerah efisiensi.

Simpulan : Trend efisiensi penggunaan tempat tidur RS Panti Wilasa Citarum Semarang cenderung menurun pada tahun 2015-2019. Untuk meningkatkan efisiensi, sebaiknya rumah sakit melakukan evaluasi pemakaian tempat tidur per ruangan atau kelas.
\end{abstract}

Kata kunci $\quad$ : Trend, BOR, LOS, TOI, BTO, Barber Johnson.

\section{ABSTRACT}

Background: Trend analysis is used as material for planning and evaluation to achieve better inpatient services. Figures for use of beds are indicated by BOR, LOS, TOI, and BTO. The BOR rate at Panti Wilasa Citarum Hospital in 2015 2019 has not met the efficiency standard, which is around $62 \%$. 
Purpose: This study aims to analyze the trends of BOR, LOS, TOI, BTO and Grfaik Barber Johnson at Panti Wilasa Citarum Hospital Semarang in 2015 2019.

Research method: This study is a descriptive study with a retrospective study design. Sources of data were obtained through observation and interviews with analyzing / reporting officers, while secondary data were obtained from RL 3 . Data analysis was carried out by analyzing trends and Barber Johnson Graphs.

Result: The trend of BOR has decreased every year from the highest $64.03 \%$ and the lowest $61.50 \%$. The LOS and TOI trends have decreased every year while the BTO trends have increased every year. The use of beds with the Barber Johnson Graph falls outside the efficiency area with a trend away from the Barber Johnson Graph efficiency area.

Conclusion: The trend in bed use efficiency tends to decline in 2015-2019. To increase efficiency, the hospital should evaluate the use of beds per room or class.

Keywords: Trend, BOR, LOS, TOI, BTO, Barber Johnson.

\section{PENDAHULUAN}

Rumah sakit adalah institusi pelayanan kesehatan yang menyelenggarakan pelayanan kesehatan perorangan secara paripurna yang menyediakan pelayanan rawat inap, rawat jalan, dan gawat darurat (UU No. 44 Tahun 2009). Keberhasilan rumah sakit diukur dari beberapa kemampuan yaitu menghasilkan produk pelayanan yang efektif dan efisien, melakukan pengembangan organisasi, melakukan adaptasi terhadap perubahan lingkungan dan kemampuan memberikan kepuasan bagi customer internal maupun eksternal. Di dalam penyelenggaraan rumah sakit, salah satu penunjang yang terpenting adalah terselenggaranya rekam medik yang baik dan benar (Hatta, 2012).

Rekam medik adalah berkas yang berisikan catatan dan dokumen tentang identitas pasien, pemeriksaan, pengobatan, tindakan dan pelayanan lain yang telah diberikan kepada pasien (Kemenkes, 2008). Data yang akurat dapat dijadikan sebagai bahan perencanaan dan evaluasi serta tindakan untuk mencapai pelayanan yang lebih baik. Statistik rumah sakit yaitu statistik yang bersumber pada data rekam medik, sebagai informasi kesehatan yang digunakan untuk memperoleh kapasitas bagi praktisi kesehatan, manajemen dan tenaga medik dalam pengambilan keputusan (Rustiyanto, 2012). Hubungan statistika dengan rekam medik sangatlah erat karena didalam menyediakan data atau informasi tentang kegiatan pelayanan di rumah sakit, data yang dihasilkan dari unit rekam medik dapat digunakan untuk menyusun laporan rumah sakit. Salah satu bagian unit rekam medik yang bertugas mengolah data rumah sakit adalah Analising reporting.

Statistik rumah sakit juga bermanfaat sebagai bahan acuan dan sebagai bahan evaluasi untuk meningkatkan mutu pelayanan di rumah sakit. Pengelolaan Unit Rawat Inap yang baik di rumah sakit dapat di nilai dari indikator-indikator 
dengan menggunakan parameter BOR (Bed Occupancy Rate) yaitu presentase pemakaian tempat tidur, LOS (Length Of Stay) yaitu rata-rata lama dirawat, TOI (Turn Over Internal) yaitu rata-rata lama waktu tempat tidur tidak terisi, BTO (Bed Turn Over) yaitu rata-rata produktivitas tempat tidur terisi (Sudra, 2010). Kualitas pelayanan kesehatan di suatu rumah sakit dikatakan efisien apabila angka BOR, LOS, TOI dan BTO telah sesuai dengan standar yang ditetapkan menurut Barber Johnson. Di dalam Grafik Barber Johnson terdapat sebuah area yang biasa disebut daerah efisien. Grafik Barber Johnson itu adalah perpaduan keempat parameter yaitu BOR, LOS, TOI dan BTO. Daerah efisien ditentukan dengan nilai-nilai dari ke-4 parameter tersebut. Yaitu BOR : 75\%-85\%, LOS : 3-12 hari, TOI : 1-3 hari, BTO : 30 kali (Rustiyanto, 2012). Daerah efisien digunakan untuk membantu pembaca menentukan apakah dengan nilai-nilai keempat parameter tersebut pemakaian tempat tidur pasien di sebuah rumah sakit sudah efisien atau belum.

Berdasarkan hasil survey awal di RS Panti Wilasa Citarum perhitungan salah satu indikator pelayanan rawat inap yaitu nilai BOR (Bed Occupancy Rate) menunjukkan angka tertinggi pada tahun 2015 (64,03\%) dan terendah pada tahun $2016(61,50 \%)$ yang belum mencapai tingkat efisiensi. Sedangkan standar ideal menurut Barber Johnson yaitu BOR adalah 75\%-85\%, LOS adalah 3-12 hari, TOI adalah 1-3 hari, BTO adalah 30 kali (Rustiyanto, 2012). Di Rumah Sakit Panti Wilasa Citarum juga belum terdapat Analisis trend BOR, LOS, TOI, BTO dan Grafik Barber Johnson yang berguna untuk peramalan mengenai kebutuhan tempat tidur. Berdasarkan latar belakang tersebut, serta melihat pentingnya analisa trend yang dapat dijadikan sebagai bahan perencanaan dan evaluasi, peneliti tertarik untuk melakukan penelitian yang berjudul "Analisis Trend BOR, LOS, TOI, BTO dan grafik Barber Johnson di RS Panti Wilasa Citarum Tahun 20152019.

\section{METODE}

Jenis penelitian yang digunakan adalah penelitian deskriptif, adalah suatu metode penelitian yang dilakukan dengan tujuan utama untuk membuat gambaran atau deskripsi tentang suatu keadaan secara objektif (Notoatmodjo, 2015). Pendekatan penelitian yang digunakan dalam penelitian ini adalah Cross Sectional Study yaitu penelitian dimana data yang menyangkut variabel risiko atau sebab (independent variable) maupun variabel akibat (dependent variable) dilakukan secara bersama-sama atau sekaligus. Penelitian ini penulis mengumpulkan data Rekapitulasi Laporan 3 (RL 3) Tahun 2015-2019. 


\section{HASIL DAN PEMBAHASAN}

\section{Hasil}

\section{Trend BOR di Rumah Sakit Panti Wilasa Citarum Semarang Tahun 2015 - 2019}

BOR atau Bed Occupancy Rate adalah persentase pemakaian tempat tidur pada periode tertentu. Untuk menghitung nilai BOR menggunakan rumus (Sudra, 2010):

$$
\text { BOR }=\frac{0}{A} \times 100 \%
$$

Keterangan :

$\mathrm{O}=$ Rata-rata tempat tidur yang terisi

$\mathrm{A}=$ Rata-rata tempat tidur yang siap pakai

BOR dihitung dengan membagi rata-rata tempat tidur terisi dengan ratarata tempat tidur siap pakai dan dijadikan persentase. Dari hasil penelitian di Rumah Sakit Panti Wilasa Citarum Semarang dapat diketahui nilai BOR seperti tersaji pada Tabel 1 berikut.

Tabel 1. Perhitungan BOR di Rumah Sakit Panti Wilasa Citarum Semarang Tahun 2015- 2019.

\begin{tabular}{cccccccc}
\hline No & Tahun & HP $($ Hari $)$ & T (hari) & O (HP/t) & D & A & BOR (\%) \\
\hline 1 & 2015 & 46.973 & 365 & 128,69 & 14.880 & 201 & 64,03 \\
2 & 2016 & 45.241 & 366 & 123,61 & 15.454 & 201 & 61,50 \\
3 & 2017 & 45.702 & 365 & 125,21 & 18.267 & 201 & 62,29 \\
4 & 2018 & 46.988 & 365 & 128,73 & 20.650 & 205 & 62,64 \\
5 & 2019 & 47.365 & 365 & 129,77 & 19.388 & 205 & 63,30 \\
\hline
\end{tabular}

Sumber : Data Rekapitulasi laporan RL 3 dan Hasil Perhitungan

Berdasarkan Tabel 1 dapat diketahui bahwa nilai BOR di RS Panti Wilasa Citarum Semarang nilai tertinggi pada Tahun 2015 yaitu $64,03 \%$ dan nilai terendah pada Tahun 2016 yaitu 61,50\%.

Trend merupakan suatu metode analisis yang ditujukan untuk melakukan suatu estimasi (perkiraan) atau peramalan pada masa yang akan datang. Untuk menghitung nilai trend menggunakan rumus (Fajar, 2009).

Keterangan :

$$
Y=a+b X
$$

$\mathrm{Y}=$ Variabel yang diramalkan

$\mathrm{a}=$ Nilai konstanta

$\mathrm{b}=$ Kemiringan atau perubahan nilai $\mathrm{Y}$ dari waktu ke waktu

$\mathrm{X}=$ Variabel waktu (tahun) 
Sedangkan untuk mencari nilai konstanta (a) dan parameter (b) menggunakan rumus :

$$
\begin{aligned}
& \mathbf{a}=\frac{\sum \mathbf{Y}}{\mathrm{N}} \\
& \mathbf{b}=\frac{\sum \mathbf{X Y}}{\sum \mathbf{X}^{2}}
\end{aligned}
$$

Dimana $\mathrm{N}$ adalah jumlah tahun dalam periode tertentu. Berdasarkan persamaan trend BOR diatas maka dapat diketahui trend BOR di RS Panti Wilasa Citarum Semarang Tahun 2015 - 2019 sebagai berikut :

Tabel 2 Perhitungan Trend BOR di Rumah Sakit Panti Wilasa Citarum Semarang

\begin{tabular}{|c|c|c|c|c|}
\hline No & Tahun & $\mathbf{X}$ & $\begin{array}{c}\text { Persamaan } \\
Y=62,752+(-0,032) X\end{array}$ & $\begin{array}{c}\text { Titik } \\
\text { Trend }\end{array}$ \\
\hline 1 & 2015 & -2 & $\mathrm{Y}=62,752+(-0,032) \cdot(-2)$ & 62,816 \\
\hline 2 & 2016 & -1 & $Y=62,752+(-0,032) \cdot(-1)$ & 62,784 \\
\hline 3 & 2017 & 0 & $\mathrm{Y}=62,752+(-0,032) .(0)$ & 62,752 \\
\hline 4 & 2018 & 1 & $\mathrm{Y}=62,752+(-0,032) \cdot(1)$ & 62,72 \\
\hline 5 & 2019 & 2 & $\mathrm{Y}=62,752+(-0,032) \cdot(2)$ & 62,688 \\
\hline
\end{tabular}
Tahun $2015-2019$

Sumber : Data sekunder yang diolah

Berdasarkan Tabel 2 dapat diketahui bahwa trend BOR di RS Panti Wilasa Citarum Semarang menurun dengan nilai tertinggi pada Tahun 2015 yaitu 62.816\% dan nilai terendah pada tahun 2018 yaitu 62,72\%. Gambaran efisiensi penggunaan tempat tidur RS dapat dilihat pada grafik berikut.

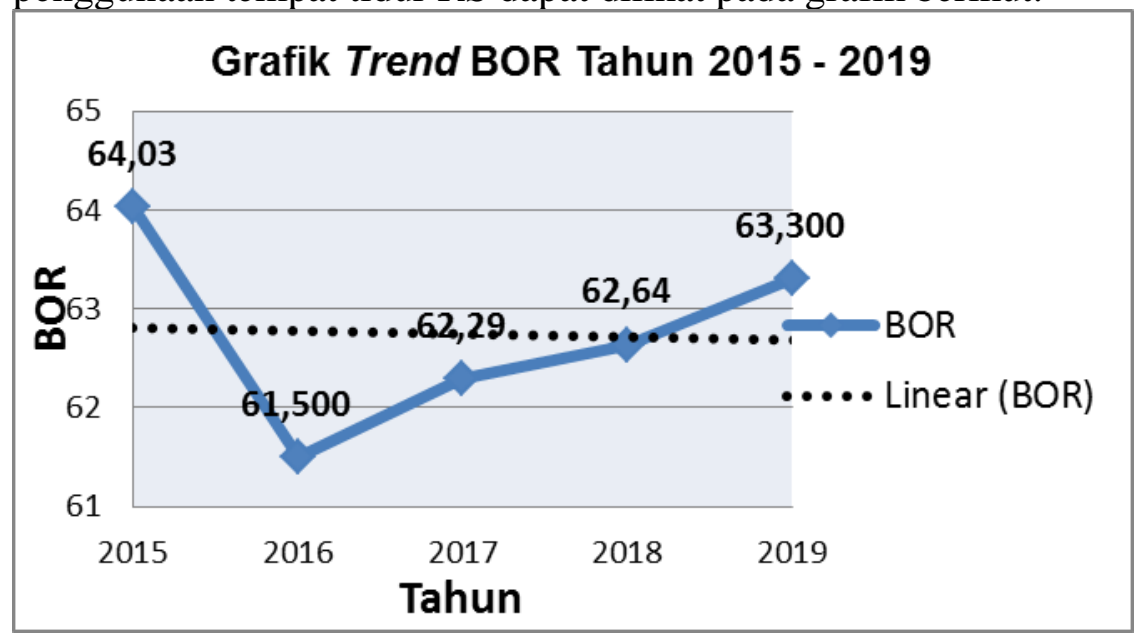

Sumber : Data sekunder yang diolah

Grafik 1 Trend BOR di RS Panti Wilasa Citarum Semarang Tahun 2015 - 2019 
Berdasarkan Grafik 1 menunjukkan bahwa trend BOR di RS Panti Wilasa Citarum Semarang Tahun 2015 - 2019 mengalami penurunan sebesar 2,53\%. Sedangkan nilai BOR tertinggi pada Tahun 2015 yaitu $64,03 \%$ dan nilai terendah pada Tahun 2016 yaitu $61,50 \%$.

\section{Trend LOS di RS Panti Wilasa Citarum Semarang Tahun 2015-2019}

LOS atau Length of Stay merupakan rata-rata jumlah hari pasien rawat inap yang tinggal di rumah sakit, tidak termasuk bayi lahir. Untuk menghitung nilai LOS menggunakan rumus (Sudra, 2010):

$$
\operatorname{LOS}=\frac{\mathbf{0} \times \mathbf{t}}{\mathrm{D}}
$$

Keterangan :

$\mathrm{O}=$ rata-rata tempat tidur yang terisi

$\mathrm{D}=$ pasien keluar $(\mathrm{H}+\mathrm{M})$

$\mathrm{t}=$ Waktu (hari/bulan/tahun)

LOS dihitung dengan cara membagi rata-rata tempat tidur terisi dalam periode tertentu dengan jumlah pasien keluar dari RS. Dari hasil penelitian di RS Panti Wilasa Citarum Semarang dapat diketahui nilai LOS pada tabel 3 berikut.

Tabel 3 Perhitungan LOS di RS Panti Wilasa Citarum Semarang tahun 2015-2019

\begin{tabular}{cccccccc}
\hline No & Tahun & $\begin{array}{c}\text { HP } \\
\text { (Hari) }\end{array}$ & $\begin{array}{c}\text { T } \\
\text { (hari) }\end{array}$ & $\begin{array}{c}\text { O } \\
\text { (HP/t) }\end{array}$ & D & A & $\begin{array}{c}\text { LOS } \\
\text { (hari) }\end{array}$ \\
\hline 1 & 2015 & 46.973 & 365 & 128,69 & 14.880 & 201 & 3,16 \\
2 & 2016 & 45.241 & 366 & 123,61 & 15.454 & 201 & 2,93 \\
3 & 2017 & 45.702 & 365 & 125,21 & 18.267 & 201 & 2,50 \\
4 & 2018 & 46.988 & 365 & 128,73 & 20.650 & 205 & 2,28 \\
5 & 2019 & 47.365 & 365 & 129,77 & 19.388 & 205 & 2,44 \\
\hline
\end{tabular}

Sumber : Data Rekapitulasi laporan RL 3

Berdasarkan Tabel 3 dapat diketahui bahwa nilai LOS di RS Panti Wilasa Citarum Semarang tertinggi pada Tahun 2015 yaitu 3,16 hari dan terendah pada Tahun 2018 yaitu 2,28 hari. Berdasarkan persamaan trend LOS diatas maka dapat diketahui trend LOS di RS Panti Wilasa Citarum Semarang Tahun 2015 - 2019 sebagai berikut

Tabel 4 Perhitungan Trend LOS di Rumah Sakit Panti Wilasa Citarum Semarang Tahun $2015-2019$ 


\begin{tabular}{|c|c|c|c|c|}
\hline No & Tahun & $\mathbf{X}$ & $\begin{array}{c}\text { Persamaan } \\
Y=2,662+(-0,109) X\end{array}$ & $\begin{array}{c}\text { Titik } \\
\text { Trend }\end{array}$ \\
\hline 1 & 2015 & -2 & $Y=2,662+(-0,109) \cdot(-2)$ & 2,88 \\
\hline 2 & 2016 & -1 & $Y=2,662+(-0,109) \cdot(-1)$ & 2,77 \\
\hline 3 & 2017 & 0 & $Y=2,662+(-0,109) .(0)$ & 2,662 \\
\hline 4 & 2018 & 1 & $Y=2,662+(-0,109) .(1)$ & 2,55 \\
\hline 5 & 2019 & 2 & $Y=2,662+(-0,109) \cdot(2)$ & 2,44 \\
\hline
\end{tabular}

Sumber : Data sekunder yang diolah

Berdasarkan Tabel 4 dapat diketahui bahwa trend LOS di RS Panti Wilasa Citarum Semarang turun dengan nilai tertinggi pada Tahun 2015 yaitu 2,88 hari dan nilai terendah pada tahun 2019 yaitu 2,44 hari.

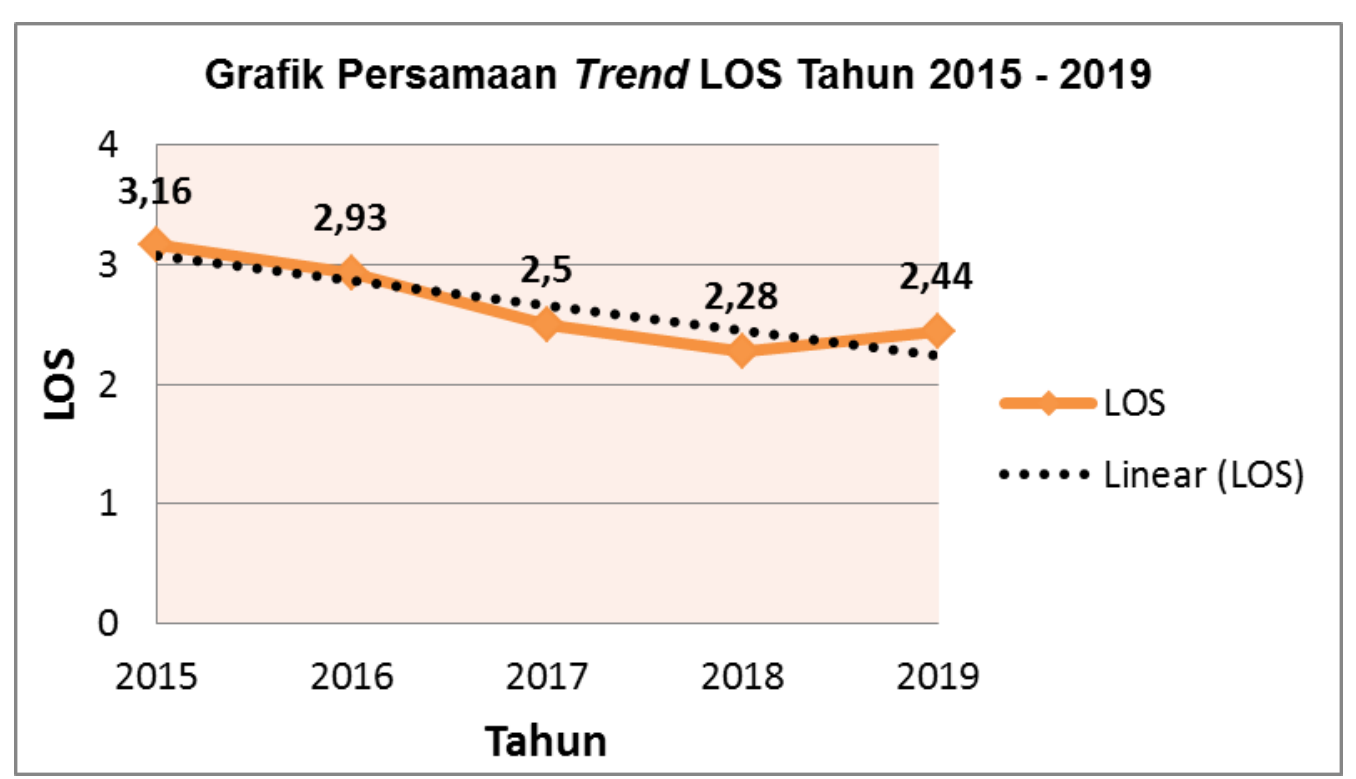

Sumber : Data sekunder yang diolah

Grafik 2 Trend LOS di RS Panti Wilasa Citarum Semarang Tahun 2015 - 2019

Berdasarkan Grafik 2 menunjukkan bahwa trend LOS di RS Panti Wilasa Citarum Semarang Tahun 2015 - 2019 mengalami penurunan setiap tahunnya. Sedangkan nilai tertinggi pada Tahun 2015 yaitu 3,16 hari dan nilai terendah pada Tahun 2018 yaitu 2,28 hari. Hasil wawancara dengan pihak rumah sakit menunjukkan bahwa LOS yang rendah bisa disebabkan karena adanya kebijakan batas waktu peserta BPJS dan kasus pelayanan persalinan tanpa operasi.

\section{Trend TOI di RS Panti Wilasa Citarum Semarang Tahun 2015-2019}

TOI atau Turn Over Interval merupakan lamanya rata-rata tempat tidur kosong atau rata-rata tempat tidur tersedia pada periode tertentu yang tidak terisi antara pasien keluar atau mati dengan pasien masuk. Untuk menghitung nilai TOI menggunakan rumus (Sudra, 2010): 


$$
\text { TOI }=\frac{(A-0) \times t}{D}
$$

Keterangan :

$\mathrm{O}=$ Rata-rata tempat tidur yang terisi

$\mathrm{A}=$ Rata-rata tempat tidur yang siap pakai

$\mathrm{D}=$ Pasien $\operatorname{keluar}(\mathrm{H}+\mathrm{M})$

$\mathrm{t}=$ Waktu (hari/bulan/tahun)

TOI dihitung dengan cara membagi rata-rata tempat tidur kosong tidak ditempat pasien dalam periode tertentu dengan pasien keluar. Dari hasil penelitian di RS Panti Wilasa Citarum Semarang dapat diketahui nilai TOI sebagai berikut :

Tabel 5 Perhitungan TOI di RS Panti Wilasa Citarum Semarang Tahun 2015 -

\begin{tabular}{|c|c|c|c|c|c|c|c|}
\hline No & Tahun & $\begin{array}{c}\text { HP } \\
\text { (Hari) }\end{array}$ & $\begin{array}{c}T \\
\text { (hari) }\end{array}$ & $\begin{array}{c}\mathbf{O} \\
(\mathbf{H P} / \mathbf{t})\end{array}$ & D & $\mathbf{A}$ & $\begin{array}{c}\text { TOI } \\
\text { (hari) }\end{array}$ \\
\hline 1 & 2015 & 46973 & 365 & 128,69 & 14880 & 201 & 1,77 \\
\hline 2 & 2016 & 45241 & 366 & 123,61 & 15454 & 201 & 1,83 \\
\hline 3 & 2017 & 45702 & 365 & 125,21 & 18267 & 201 & 1,51 \\
\hline 4 & 2018 & 46988 & 365 & 128,73 & 20650 & 205 & 1,34 \\
\hline 5 & 2019 & 47365 & 365 & 129,77 & 19388 & 205 & 1,41 \\
\hline
\end{tabular}

Sumber : Data Rekapitulasi laporan 3 dan Hasil Perhitungan

Berdasarkan Tabel 5 dapat diketahui bahwa nilai TOI di RS Panti Wilasa Citarum Semarang tertinggi pada Tahun 2016 yaitu 1,83 hari dan terendah pada tahun 2018 yaitu 1,34 hari. Berdasarkan persamaan trend TOI diatas maka dapat diketahui trend TOI di RS Panti Wilasa Citarum Semarang Tahun 2015 - 2019 sebagai berikut :

Tabel 6 Perhitungan Trend TOI di Rumah Sakit Panti Wilasa Citarum Semarang Tahun $2015-2019$

\begin{tabular}{|c|c|c|c|c|}
\hline No & Tahun & $\mathbf{X}$ & $\begin{array}{c}\text { Persamaan } \\
Y=1,572+(-0,121) X\end{array}$ & $\begin{array}{c}\text { Titik } \\
\text { Trend }\end{array}$ \\
\hline 1 & 2015 & -2 & $\mathrm{Y}=1,572+(-0,121) \cdot(-2)$ & 1,81 \\
\hline 2 & 2016 & -1 & $Y=1,572+(-0,121) \cdot(-1)$ & 1,69 \\
\hline 3 & 2017 & 0 & $\mathrm{Y}=1,572+(-0,121) \cdot(0)$ & 1,572 \\
\hline 4 & 2018 & 1 & $\mathrm{Y}=1,572+(-0,121) \cdot(1)$ & 1,45 \\
\hline 5 & 2019 & 2 & $\mathrm{Y}=1,572+(-0,121) \cdot(2)$ & 1,33 \\
\hline
\end{tabular}

Sumber : Data sekunder yang diolah 
Berdasarkan Tabel 6 dapat diketahui bahwa trend TOI di RS Panti Wilasa Citarum Semarang turun dengan nilai tertinggi pada Tahun 2015 yaitu 1,81 hari dan nilai terendah pada Tahun 2019 yaitu 1,33 hari.

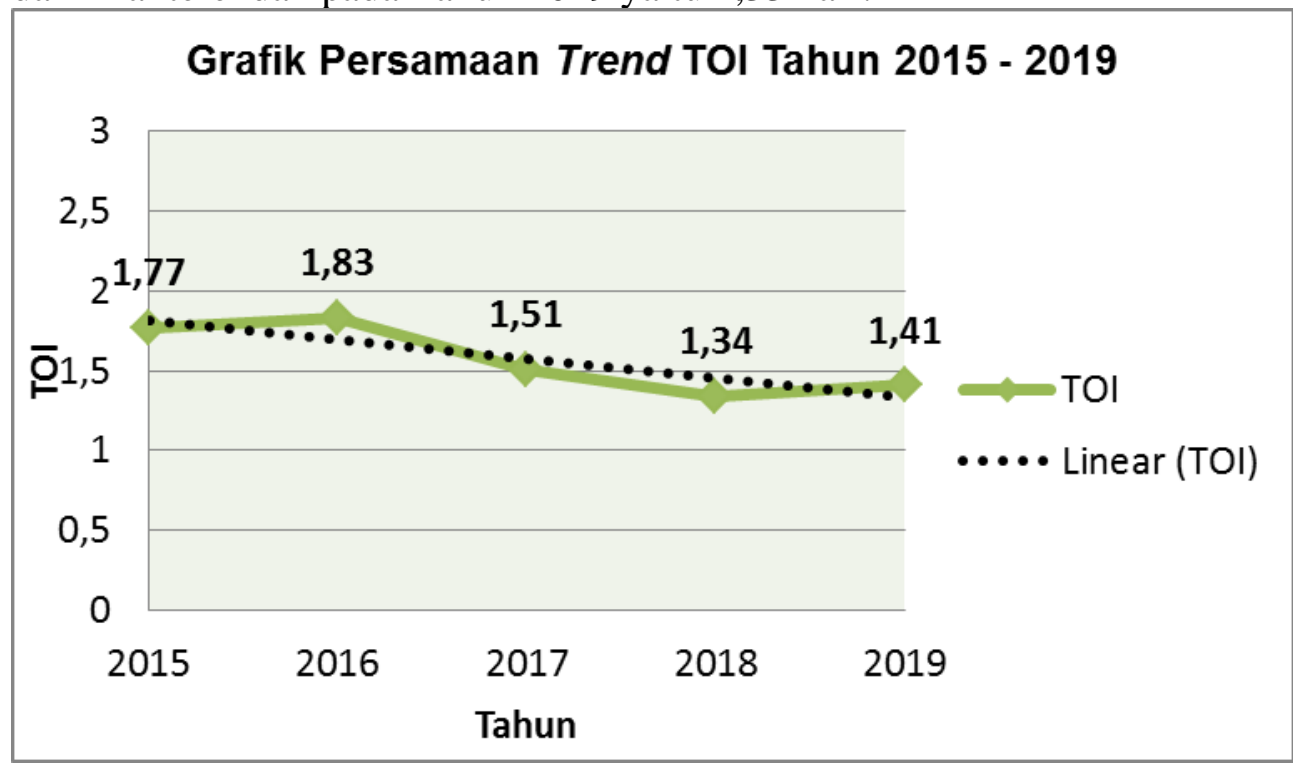

Sumber : Data sekunder yang diolah

Grafik 3 Trend TOI di RS Panti Wilasa Citarum Semarang Tahun 2015 - 2019

Berdasarkan Grafik 3 menunjukkan bahwa trend TOI di RS Panti Wilasa Citarum Semarang Tahun 2015 - 2019 mengalami kenaikan pada Tahun 2016 dari 1,77 hari menjadi 1,83 hari. Sedangkan nilai TOI tertinggi pada Tahun 2016 yaitu 1,83 hari dan nilai terendah pada Tahun 2018 yaitu 1,34.

\section{Trend BTO di RS Panti Wilasa Citarum Semarang Tahun 2015-2019}

BTO atau Bed Turn Over merupakan berapa kali satu tempat tidur dipakai oleh pasien dalam periode tertentu. Untuk menghitung nilai BTO menggunakan rumus :

$$
\text { BTO }=\frac{\mathbf{D}}{\mathrm{A}}
$$

Keterangan :

$\mathrm{A}=$ Rata-rata tempat tidur yang siap pakai

$\mathrm{D}=$ Pasien keluar $(\mathrm{H}+\mathrm{M})$

BTO dihitung dengan cara membagi jumlah pasien keluar dengan rata-rata tempat tidur siap pakai. Dari hasil penelitian yang dilakukan di RS Panti Wilasa Citarum Semarang dapat diketahui nilai BTO sebagai berikut : 
Tabel 7 Perhitungan BTO di RS Panti Wilasa Citarum Semarang Tahun 20152019

\begin{tabular}{cccccccc}
\hline No & Tahun & $\begin{array}{c}\text { HP } \\
\text { (Hari) }\end{array}$ & $\begin{array}{c}\text { T } \\
\text { (hari) }\end{array}$ & $\begin{array}{c}\text { O } \\
\text { (HP/t) }\end{array}$ & D & A & $\begin{array}{c}\text { BTO } \\
\text { (kali) }\end{array}$ \\
\hline 1 & 2015 & 46973 & 365 & 128,69 & 14880 & 201 & 74,03 \\
2 & 2016 & 45241 & 366 & 123,61 & 15454 & 201 & 76,89 \\
3 & 2017 & 45702 & 365 & 125,21 & 18267 & 201 & 90,88 \\
4 & 2018 & 46988 & 365 & 128,73 & 20650 & 205 & 100,73 \\
5 & 2019 & 47365 & 365 & 129,77 & 19388 & 205 & 94,58 \\
\hline
\end{tabular}

Sumber : Data Rekapitulasi laporan RL 3 yang diolah

Berdasarkan Tabel 7 dapat diketahui bahwa nilai BTO di RS Panti Wilasa citarum Semarang tertinggi pada tahun 2018 yaitu 100,73 kali dan terendah pada Tahun 2015 yaitu 74,04 kali. Berdasarkan persamaan trend BTO diatas maka dapat diketahui trend BTO di RS Panti Wilasa Citarum Semarang Tahun 2015 2019 sebagai berikut :

Tabel 8 Perhitungan Trend BTO di Rumah Sakit Panti Wilasa Citarum Semarang Tahun $2015-2019$

\begin{tabular}{ccccc}
\hline No & Tahun & $\mathbf{X}$ & Persamaan & Titik \\
\cline { 4 - 5 } & & & $\mathrm{Y}=87,42+(6,494) \mathrm{X}$ & 74,43 \\
\hline 1 & 2015 & -2 & $\mathrm{Y}=87,42+(6,494) .(-2)$ & 80,92 \\
2 & 2016 & -1 & $\mathrm{Y}=87,42+(6,494) .(-1)$ & 87,42 \\
3 & 2017 & 0 & $\mathrm{Y}=87,42+(6,494) .(0)$ & 93,91 \\
4 & 2018 & 1 & $\mathrm{Y}=87,42+(6,494) .(1)$ & 100,408 \\
5 & 2019 & 2 & $\mathrm{Y}=87,42+(6,494) .(2)$ & \\
\hline
\end{tabular}

Sumber : Hasil Penelitian

Berdasarkan Tabel 8 dapat diketahui bahwa trend BTO di RS Panti Wilasa Citarum Semarang naik dengan nilai tertinggi pada Tahun 2019 yaitu 100,408 kali dan nilai terendah pada Tahun 2015 yaitu 74,43 kali. 


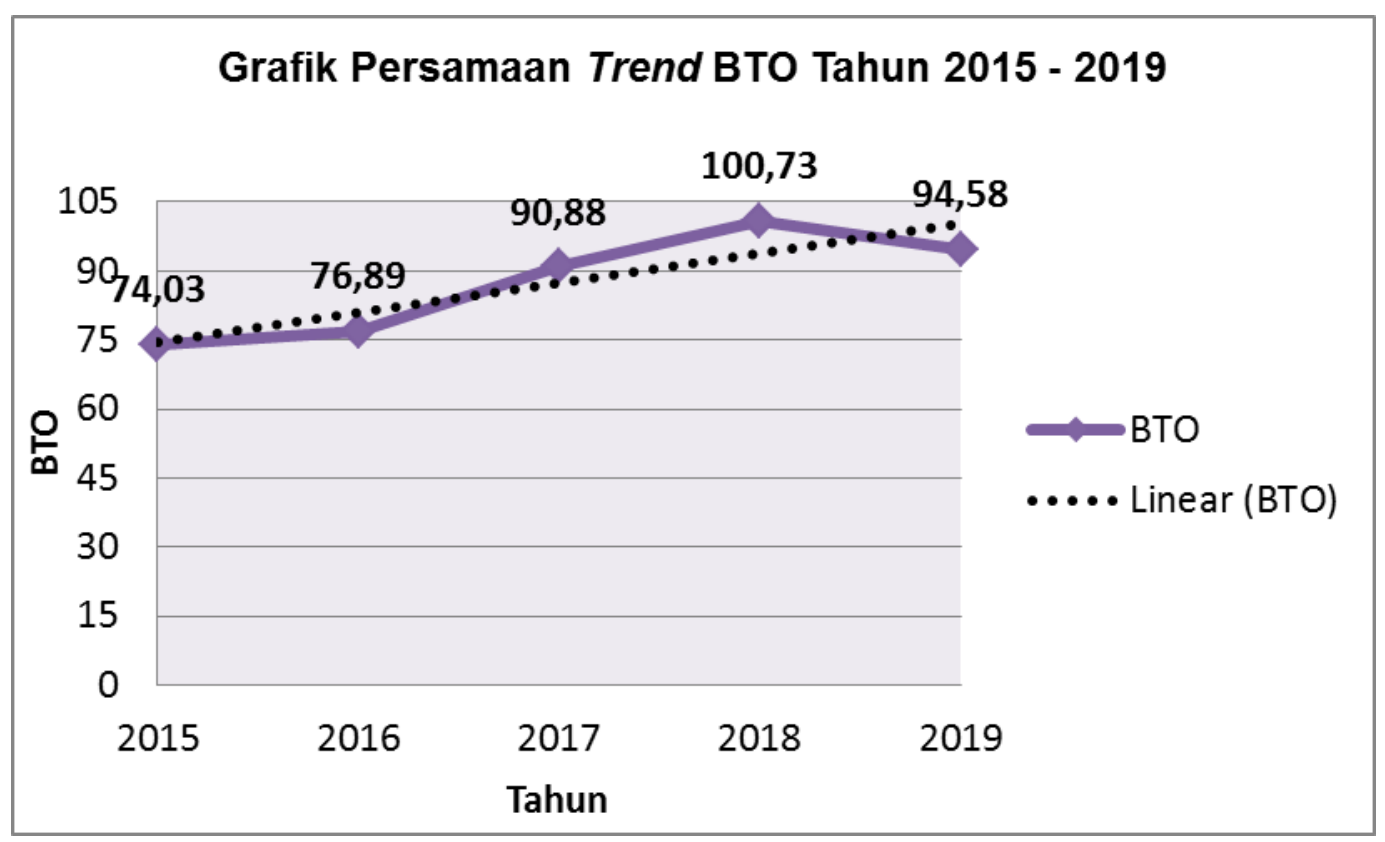

Sumber : Data sekunder yang diolah

Grafik 4 Trend BTO di RS Panti Wilasa Citarum Semarang Tahun 2015 - 2019

Berdasarkan Grafik 4.4 menunjukkan bahwa trend BTO di RS Panti Wilasa Citarum Semarang Tahun 2015 - 2018 mengalami kenaikan setiap Tahunnya. Sedangkan nilai BOR tertinggi pada Tahun 2019 yaitu 100,73 kali dan nilai terendah pada Tahun 2017 yaitu 74,03 kali.

\section{Efisiensi BOR, LOS, TOI, BTO Berdasarkan Grafik Barber Johnson di RS Panti Wilasa citarum Semarang Tahun 2015 - 2019}

Gambaran efisiensi penggunaan tempat tidur dapat digambarkan dengan Grafik Barber Johnson. Grafik ini menggambarkan secara visul penggunaan tempat tidur dengan empat parameter yaitu BOR, LOS, TOI, dan BTO dalam satu titik. Jika titik BJ berada di dalam daerah efisien dapat dikatakan bahwa penggunaan tempat tidur RS sudah efisien (Rustiyanto, 2012). Berikut gambaran penggunaan tempat tidur dengan Grafik Barber Johnson untuk RS Panti Wilasa Citarum Tahun 2015-2019. 


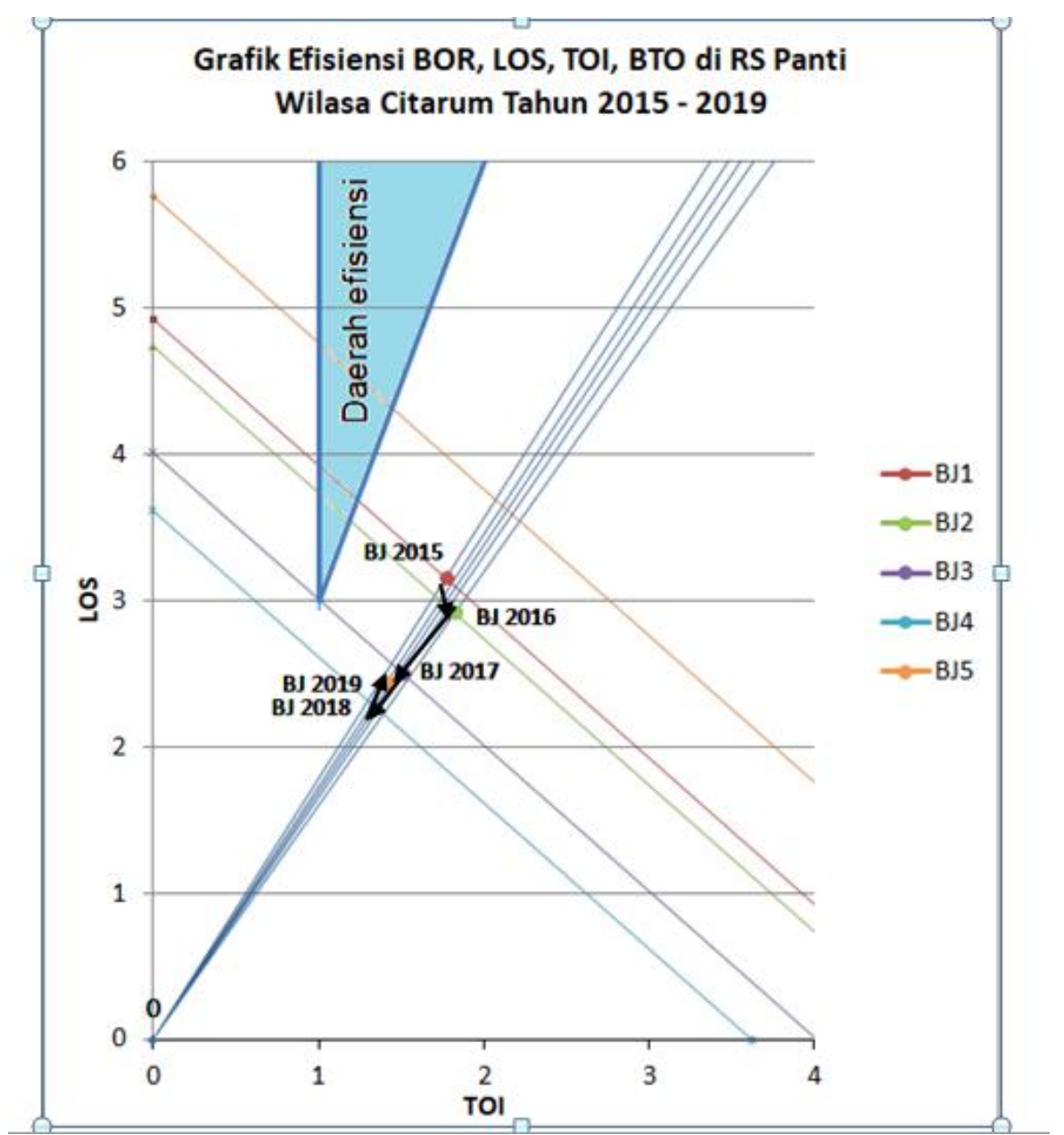

Sumber : Data sekunder yang diolah

Grafik 5 Efisiensi BOR, LOS, TOI, BTO Berdasarkan Grafik Barber Johnson di RS Panti Wilasa citarum Semarang Tahun 2015 - 2019

Titik Barber Johnson tahun 2015, 2016, 2017, 2018 dan 2019 belum memenuhi standar efisiensi. Dalam menentukan efisiensi pelayanan rawat inap peneliti menggunakan standar efisiensi dari Barber Johnson, ada empat parameter Barber Johnson yaitu BOR, LOS, TOI, dan BTO. Bersumber dari Rekapitulasi Laporan 3 (RL.3) hasil perhitungan trend BOR, LOS, TOI, BTO dapat diketahui. Berdasarkan standar efisiensi Barber Johnson yaitu antara 75\% - 85\% angka trend BOR di RS Panti Wilasa Citarum Semarang Tahun 2015 - 2019 masih belum memenuhi standar efisiensi

\section{Pembahasan}


Nilai BOR di RS Panti Wilasa Citarum Semarang nilai tertinggi pada Tahun 2015 yaitu 64,03\% dan nilai terendah pada Tahun 2016 yaitu 61,50\%. Standar BOR ideal menurut Barber Johnson adalah minimal 75\%, berarti BOR di RS Panti Wilasa Citarum belum efisien. Sejalan dengan penelitian Aulia (2019) yaitu BOR yang tidak sesuai dengan standar yaitu di bawah $75 \%$, akan tetapi jika mengikuti standar dari Depkes (BOR ideal 60\% - 80\%) maka angka BOR sudah ideal. Trend BOR di RS Panti Wilasa Citarum Semarang Tahun 2015 - 2019 mengalami penurunan sebesar $2,53 \%$. Sedangkan nilai BOR tertinggi pada Tahun 2015 yaitu 64,03\% dan nilai terendah pada Tahun 2016 yaitu 61,50\%. Menurut Rano (2010) semakin tinggi nilai BOR berarti semakin tinggi pula penggunaan tempat tidur yang tersedia untuk perawatan pasien dan sebaliknya. BOR yang rendah akan mengakibatkan tidak efisiennya manajemen keuangan RS karena kurangnya pemasukan. Diperlukan evaluasi kualitas pelayanan dan jejaring pelayanan dengan fasilitas pelayanan kesehatan sehingga dapat meningkatkan pemakaian tempat tidur RS.

Trend LOS di RS Panti Wilasa Citarum Semarang Tahun 2015 - 2019 mengalami penurunan setiap tahunnya. Sedangkan nilai tertinggi pada Tahun 2015 yaitu 3,16 hari dan nilai terendah pada Tahun 2018 yaitu 2,28 hari. LOS RS Panti Wilasa Citarum semakin menurun sampai batas minimal standar ideal yaitu 3- 12 hari. Dari aspek medis, semakin lama angka LOS maka bisa menunjukkan kinerja kualitas medis yang kurang baik karena pasien harus dirawat lebih lama. Dari aspek ekonomis, semakin lama nilai LOS berarti semakin tinggi biaya yang nantinya harus dibayar oleh pasien kepada pihak rumah sakit. Diperlukannya adanya keseimbangan antara sudut pandang medis dan ekonomis untuk menentukan nilai LOS yang ideal (Sudra, 2010). Hasil wawancara dengan pihak rumah sakit menunjukkan bahwa LOS yang rendah bisa disebabkan karena adanya kebijakan batas waktu peserta BPJS dan kasus pelayanan persalinan tanpa operasi. Sejalan dengan penelitian dari Irmawati (2018), maka upaya menjaga nilai lama hari pasien dirawat (LOS) agar sesuai nilai LOS ideal Barber Johnson, perlu adanya kebijakan dari manajemen rumah sakit untuk terus meningkatkan mutu pelayanan.

Trend TOI di RS Panti Wilasa Citarum Semarang Tahun 2015 - 2019 mengalami kenaikan pada Tahun 2016 dari 1,77 hari menjadi 1,83 hari. Sedangkan nilai TOI tertinggi pada Tahun 2016 yaitu 1,83 hari dan nilai terendah pada Tahun 2018 yaitu 1,34. Nilai TOI RS masih dalam batas ideal (1-3 hari). Semakin kecil angka TOI, berarti semakin singkat saat TT menunggu pasien berikutnya. Hal ini bisa menguntungkan secara ekonomis bagi pihak manajemen rumah sakit tapi bisa merugikan pasien karena kurangnya waktu untuk melakukan sterilisasi ruangan. Akibatnya, kejadian infeksi nosokomial mungkin bisa meningkat, beban kerja tim medis meningkat sehingga kepuasan dan keselamatan pasien terancam. (Sudra, 2010).

Trend BTO di RS Panti Wilasa Citarum Semarang Tahun 2015 - 2018 mengalami kenaikan setiap Tahunnya. Sedangkan nilai BOR tertinggi pada Tahun 
2019 yaitu 100,73 kali dan nilai terendah pada Tahun 2017 yaitu 74,03 kali. BTO sudah menunjukkan nilai ideal Barber Johnson yaiitu minimal 30 pasien dalam setahun. Semakin tinggi angka BTO berarti setiap tempat tidur yang tersedia digunakan oleh semakin banyak pasien secara bergantian. Hal ini tentu menguntungkan bagi pihak rumah sakit namun beban kerja tim perawatan sangat tinggi dan TT tidak sempat disterilisasi karena terus digunakan pasien secara bergantian. Kondisi ini mudah menimbulkan ketidakpuasan pasien, bisa mengancam keselamatan pasien (patient safety), bisa menurunkan kinerja kualitas medis, dan bisa meningkatkan kejadian infeksi nosokomial karena TT tidak sempat dibersihkan atau disterilkan. (Sudra, 2010). Diperlukan evaluasi pemakaian tempat tidur dengan melihat tiap bangsal atau kelas. Kelas atau bangsal dengan permintaan tempat tidur yang rendah dapat dilakukan relokasi ke bangsal atau kelas yang tinggi permintaan tempat tidurnya.

Angka trend BOR yang mengalami penurunan akan mempengaruhi angka trend TOI (Afriani, 2017 dan Lesiangi, 2019). Hal ini disebabkan tinggi rendahnya angka trend BOR akan berdampak pada tinggi rendahnya angka TOI. Angka trend TOI di RS Panti Wilasa Citarum Semarang Tahun 2015 - 2019 mengalami penurunan dari batas standar efisiensi Barber Johnson yaitu antara 1 3 hari. TOI merupakan lamanya rata - rata tempat tidur kosong atau rata - rata tempat tidur tersedia pada periode tertentu yang tidak terisi antara pasien keluar atau mati dengan pasien masuk. Trend TOI turun maka permintaan tempat tidur meningkat karena semakin rendah angka TOI maka jarak tempat tidur kosong antara pasien keluar dengan masuk menjadi dekat (Sunami, 2015).

Sedangkan angka trend LOS merupakan angka yang menunjukan lama perawatan. Batas standar efisiensi trend LOS berdasarkan Barber Johnson yaitu antara 3 - 12 hari. Angka trend LOS di RS Panti Wilasa Citarum Semarang dari Tahun 2015 - 2019 belum memenuhi standar efisiensi Barber Johnson. Hal ini dapat dilihat dari angka trend LOS di RS Panti Wilasa Citarum Semarang dari Tahun 2015 - 2019 yang mengalami penurunan. Angka trend BOR, LOS dan TOI akan mempengaruhi trend BTO (Irwan, 2018). Angka trend BTO merupakan frekuensi pemakaian tempat tidur. Batas standar efisiensi trend BTO berdasarkan Barber Johnson yaitu sebanyak 30 kali pemakaian pertahun. Angka trend BTO di RS Panti Wilasa Citarum Semarang dari Tahun 2015 - 2019 mengalami kenaikan yang jauh dari standar efisiensi Barber Johnson.

Berdasarkan Grafik Barber Johnson diketahui bahwa penggunaan tempat tidur RS Panti Wilasa Citarum Semarang Tahun 2015 - 2019 belum efisiensi karena tidak memasuki daerah efisiensi barber johnson. Untuk angka trend BOR Tahun 2015 - 2019 masih di bawah standar Barber Johnson sehingga titiknya masih di luar daerah efisiensi. Angka trend LOS di RS Panti Wilasa Citarum Semarang dari Tahun 2015 - 2019 sudah memenuhi standar Barber Johnson. Angka trend TOI di RS Panti wilasa Citarum Semarang dari Tahun 2015 - 2019 sudah sesuai standar Barber Johnson. Angka BTO Tahun 2015 - Tahun 2019 belum memenuhi standar Barber Johnson, sehingga titik Barber Johnson berada di luar daerah efisiensi. Penelitian Rinjani (2016) dan Devi (2019) 
menunjukkan bahwa analisis efisiensi penggunaan tempat tidur tiap bangsal dan kelas dapat memberikan evaluasi lebih detail sehingga manajemen ruangan dapat lebih optimal.

\section{KESIMPULAN DAN SARAN}

\section{Kesimpulan}

Trend BOR di RS Panti Wilasa Citarum Semarang Tahun 2015 - 2019 mengalami penurunan setiap tahunnya sebesar 2,53\% dari yang tertinggi $64,03 \%$ dan yang terendah 61,50\%. Trend LOS di RS Panti Wilasa Citarum Semarang Tahun 2015 - 2019 mengalami penurunan setiap tahunnya sebesar 0,88 dari yang tertinggi 3,16 hari dan yang terendah 2,28 hari. Trend TOI di RS Panti Wilasa Citarum Semarang Tahun 2015 - 2019 mengalami penurunan setiap tahunnya sebesar 0,49 hari dari yang tertinggi 1,83 hari dan terendah 1,34 hari. Trend BTO di RS Panti Wilasa Citarum Semarang Tahun 2015 - 2019 mengalami peningkatan setiap tahunnya sebesar 26,7 kali dari yang terendah 74,03 kali dan tertinggi 100,73 kali. Efisiensi Grafik Barber Johnson di RS Panti Wilasa Citarum Semarang Tahun 2015 - 2019 berada di luar daerah efisiensi dan trend nya menjauhi daerah efisiensi grafik Barber Johnson.

\section{Saran}

Untuk meningkatkan nilai BOR sebaiknya melakukan evaluasi pemakaian tempat tidur per ruangan atau kelas. Rumah Sakit dapat membuat Grafik Barber Johnson untuk lebih mudah melihat tingkat efisiensi BOR, LOS, TOI, BTO. Nilai BTO nya yang terlalu tinggi bisa dilakukan pengaturan tempat tidur tiap ruang. Agar nilai LOS nya agar tidak terlalu kecil, sebaiknya melakukan evaluasi lebih detail pemakaian tempat tidur per kelas dan bangsal.

\section{DAFTAR PUSTAKA}

Afriani Medina, Risa. 2017. Analisis Efisiensi Penggunaan Tempat Tidur Berdasarkan Grafik Barber Johnson Pada Ruang VIP Wijaya Kusuma di RSUD Ambarawa Tahun 2016.[Karya Tulis Ilmiah]. Politeknik Kesehatan Kemenkes Semarang.

Aulia Dwijayanti, Vavi. 2019. Prediksi Kebutuhan Tempat Tidur Pada Bangsal Yang Tidak Efisien di RSUD Ungaran Berdasarkan Standar Ideal Barber Johnson Tahun 2019 - 2023. [Karya Tulis Ilmiah]. Stikes hakli.

Notoatmodjo, Soekidjo. Matodologi Penelitian Kesehatan. Penerbit PT Rineka Cipta, Jakarta, 2015.

Devi, Erna Septiana dan Asih Prasetyowati. 2019. Trend Penggunaan Tempat Tidur Menurut Kelas Di Rsud Tugurejo Semarang Tahun 2013 - 2017. Prosiding Call For Paper SMIKNAS. 
Fajar, Ibnu. 2009. Statistika Untuk Praktisi kesehatan. Edisi pertama. Graha Ilmu. Yogyakarta.

Hatta, Gemala R. 2012. Pedoman Manajemen Informasi Kesehatan di Sarana Pelayanan Kesehatan. Universitas Indonesia. Jakarta.

Huffman, E K. Medical Records Management. Physicians Record Company. Illiois. 1994

Irmawati, dkk. 2018. Efisiensi Penggunaan Tempat Tidur Berdasarkan Grafik Barber Johnson. Jurnal Rekam Medis dan Informasi Kesehatan Volume 1 Nomor 2 (Oktober 2018).

Irwan, B. 2018. Analisa Kunjungan Pasien Rawat Inap Berdasarkan Grafik Barber Johnson di Rumah Sakit Roemani Muhammadiyah Semarang Tahun 2017. [Karya Tulis Ilmiah]. Stikes Hakli. Semarang.

Kemenkes RI. 2008. Peraturan Menteri Kesehatan No 269/MENKES/PER/III/2008 tentang Rekam Medis. Jakarta.

Lesiangi, Didimus. 2019. Analisis Efisiensi Penggunaan Tempat Tidur Berdasarkan Grafik Barber Johnson di Rumah Sakit Panti Wilasa "Dr. Cipto” Semarang Triwulan I (Januari, Februari, Maret) Tahun 2019. [karya Tulis Ilmiah]. Stikes Hakli.

Rinjani, Viki, dan Endang Triyanti. 2016. Analisis Efisiensi Penggunaan Tempat Tidur per Ruangan Berdasarkan Indikator Depkes dan Barber Johnson di Rumah Sakit Singaparna Medika Citra Utama Kabupaten Tasikmalaya Triwulan 1 Tahun 2016. Jurnal MIKI, Vol 4, No.2.

Rustiyanto, Ery. 2010. Statistik Rumah Sakit Untuk Pengambilan Keputusan. Graha Ilmu. Yogyakarta.

Sidiq, Rapitos, dan Reka Afrina. 2017. Kajian Efisiensi Pelayanan Rumah Sakit. Idea Nursing Journal Vol. VIII No. 1.

Sudra, Rano Indardi. 2010. Statistik Rumah Sakit dari Sensus Pasien dan Grafik Barber Johnson Hingga statistik kematian dan otopsi. Graha Ilmu. Yogyakarta.

Sunami, Anis. 2016. Deskripsi angka TOI di bangsal Dewi Kunthi bulan Januari - Juni 2015 RSUD Kota Semarang.[Karya Tulis ilmiah]. Stikes Hakli. Semarang.

Undang-undang No 44 Tahun 2009 tentang Rumah Sakit. Lembaran Negara RI tahun 2009 No 153. Sekretariat Negara. Jakarta. 